\title{
HUBUNGAN KONTAMINASI COLIFORM DAN SKOR PERILAKU HIGIENE SANITASI PADA PEDAGANG JAJANAN DI KANTIN SEKOLAH DAN PEDAGANG KELILING
}

\author{
Correlation of Coliform Contamination and Hygiene Sanitation Behavior Scores in Snack \\ Vendors in School Canteen and Street Vendors
}

\author{
Andhita Riana ${ }^{1 *}$, Sri Sumarmi \\ ${ }^{1}$ Program Sarjana Gizi, Fakultas Kesehatan Masyarakat, Universitas Airlangga, Surabaya \\ ${ }^{2}$ Departemen Gizi Kesehatan, Fakultas Kesehatan Masyarakat, Universitas Airlangga, Surabaya \\ E-mail: andhitarian@gmail.com
}

\begin{abstract}
ABSTRAK
Makanan merupakan salah satu aspek yang dapat memengaruhi kesehatan sehingga harus aman. Kejadian luar biasa akibat keracunan makanan 19\% terjadi di Sekolah dan 78,57\% menimpa anak sekolah dasar. Higiene dan sanitasi merupakan faktor penting dalam keamanan pangan. Penelitian ini bertujuan untuk menganalisis hubungan antara perilaku hygiene dan sanitasi pedagang dengan keamanan makanan yang dinilai dengan indikator most probable number coliform. Penelitian ini merupakan jenis penelitian observasional dengan desain cross sectional. Sebesar 25 pedagang dan 25 sampel makanan dipilih secara acak. Hasil penelitian menunjukkan $40 \%$ makanan jajanan terkontaminasi Coliform (> 10 juml./g). Kontaminasi tertinggi Coliform $>1.100$ juml./g dan ditemukan pada empat snack yang dijual di kantin sekolah. Kategori Skor pengetahuan pedagang sebagian besar termasuk kategori cukup (52\%). Mayoritas pedagang termasuk dalam kategori skor sikap higiene sedang (52\%), serta sebagian besar pedagang termasuk dalam kategori skor tindakan higiene sedang dan sanitasi lingkungan sedang (masing-masing 56\%). Berdasarkan analisis statistik menggunakan uji Spearman's rho test menunjukkan terdapat hubungan signifikan antara pengetahuan, tindakan higiene dan sanitasi lingkungan pedagang dengan keamanan makanan indikator MPN Coliform (berturut-turut $p=0,022, p=0,005, p=0,000$ ). Sikap tidak berhubungan secara signifikan dengan keamanan makanan indikator MPN Coliform $(p=0,088)$. Ditemukannya $40 \%$ makanan jajanan yang terkontaminasi Coliform yang perlu diwaspadai. Observasi mengenai proses pengolahan makanan perlu dilakukan untuk pencegahan kontaminasi Coliform pada makanan jajanan anak sekolah.
\end{abstract}

Kata kunci: coliform, higiene, sanitasi, keamanan makanan, jajanan, most probable number

\begin{abstract}
Food is one of components that can cause illness, so it must be safe. An outbreaks of food poisoning $19 \%$ happened in school and $78.57 \%$ happened to elementary school children. Hygiene and sanitation are important factors related to food safety. This study was aimed to analyze correlation between behavior of hygiene and sanitation of food vendors with food safety by using most probable number of coliform indicator. This was an observational study used cross sectional design, involving 25 food vendors and 25 food sample which were selected randomly. Result showed that $40 \%$ of the snacks were contaminated by Coliform (>10 Juml. $/ \mathrm{g}$ ). The highest contamination of Coliform was $>1.100$ Juml./g and was found on four food snacks sold in the canteen. Categories of hygiene knowledge score of vendors ware moderate (52\%). The majority of vendors ware included in the moderate hygiene attitude score category (52\%), and most of the vendors ware included in the moderate hygiene practice score category and moderate environment sanitation score category (56\%, respectively). Statistical analysis using Spearman's rho test showed that there ware a significant correlation between knowledge of hygiene, practice of hygiene, and environment sanitation of vendors with food safety using indicator most probable number of coliform ( $p=0.022, p=0.005, p=0.000$, respectively). Whereas no significant correlation found between attitude of hygiene with contamination of Coliform ( $p=0.088$ ). It was Found as much as $40 \%$ of foods are contaminated by coliform and should be awared, observations of food processing needs to be applied to prevent coliform contamination of school children's snacks.
\end{abstract}

Keywords: coliform, hygiene, sanitation, food safety, snack, most probable number

Andhita Riana, et al., MGI(2018) 27-32

DOI: 10.20473/mgi.v13i1.27-32. 


\section{PENDAHULUAN}

Makanan dapat menjadi salah satu penyebab dari gangguan kesehatan (Thaheer, 2005). Makanan siap saji harus memperhatikan aspek keamanan, mutu, dan bergizi sesuai dengan Peraturan Pemerintah RI. Kontaminasi mikroba merupakan salah satu penyebab makanan menjadi tidak aman (Thaheer, 2005). Laporan kesehatan tahun 2016 bulan januari sampai juni di Indonesia terindikasi terdapat 60 kasus keracunan akibat makanan, 16,7\% diantaranya disebabkan karena cemaran pada makanan jajanan (BPOM RI, $2016_{\mathrm{a}, \mathrm{b}}$ ). Profil kesehatan provinsi Jawa Timur menunjukkan bahwa kejadian luar biasa akibat keracunan makanan ditemukan sebanyak 60 kasus, dengan jumlah korban 106 orang dan 3 orang meninggal (Dinkes Provinsi Jatim, 2012). Pada profil kesehatan kota Surabaya ditemukan sebanyak 35 kasus yaitu terjadi di 28 kelurahan (Dinkes Kota Surabaya, 2015). Laporan kejadian luar biasa (KLB) keracunan makanan menunjukkan bahwa 19\% kasus terjadi di sekolah dan sekitar $78,57 \%$ menimpa anak sekolah dasar (Kristianto, 2013).

Higiene dan sanitasi merupakan masalah serius dalam produksi makanan, personal hygiene yang buruk, penanganan makanan yang tidak tepat serta alat pengolahan yang tidak bersih merupakan penyebab utama makanan tercemar (Zulaekah, 2012). Laporan tahunan menunjukkan penemuan mengenai kandungan mikroba pada sampel makanan, dimana sebanyak 340 sampel makanan terkontaminasi Coliform (BPOM, 2015). Keberadaan Coliform dalam makanan atau minuman dapat mengindikasikan terjadinya kontaminasi akibat cara menangani makanan yang kurang tepat (Susana dan Hartono, 2003). Penelitian yang dilakukan pada salah satu SD di Bandar Lampung menunjukkan mikroba yang paling banyak mengontaminasi makanan jajanan adalah Coliform (93,75\%) (Selian, 2014). Penelitian yang dilakukan pada 866 SD/Madrasah Ibtidaiyah yang tersebar di 30 kota di Indonesia menunjukkan bahwa dari 4.808 makanan jajanan, sebesar 35,46\% diketahui tidak memenuhi syarat keamanan dan mutu makanan (BPOM, 2011). Pemeriksaan cemaran kontaminasi menunjukkan sebesar $11,86 \%$ makanan jajanan terkontaminasi
Coliform melebihi batas maksimal (BPOM, 2011). Kontaminasi terhadap makanan dapat mengakibatkan terjadinya food borne disease.

Salah satu kelompok umur yang berisiko tinggi mengalami food borne disease yaitu anak sekolah. Food borne disease dapat ditularkan melalui makanan yang disiapkan di rumah bahkan di kantin sekolah atau penjaja makanan keliling (Handoyo, 2014). Kejadian keracunan makanan pada anak sekolah dapat dicegah, salah satunya dengan mengawasi keamanan makanan jajanan anak sekolah. Higiene dan sanitasi pedagang makanan jajanan merupakan salah satu aspek penting yang perlu diperhatikan dalam upaya peningkatan keamanan pangan jajanan anak sekolah. Penelitian ini bertujuan untuk menganalisis hubungan antara perilaku hygiene dan sanitasi pedagang dengan keamanan makanan dengan indikator most probable number coliform.

\section{METODE}

Penelitian observasional ini menggunakan desain cross sectional. Sebanyak 25 pedagang jajanan dan 25 sampel makanan dipilih secara acak dengan menggunakan simple random sampling. Penelitian dilakukan pada Juli-Agustus 2017 di lima sekolah di Kecamatan Rungkut. Aspek keamanan makanan dilihat dari adanya kontaminasi mikrobiologi dengan indikator Most Probable Number Coliform. Analisis MPN Coliform dilakukan di laboratorium sanitasi Balai Besar Laboratorium Kesehatan Surabaya.

Pemeriksaan dengan metode MPN dilakukan menggunakan media lactose broth, brilliant green bile broth (BGLB), eosin methylen blue (EMB), mac conkey agar (MCA), dan IMVic seluruhnya menggunakan media produksi dari Merck. Reagen yang digunakan antara lain alfa naphtol $6 \%, \mathrm{KOH}$ $40 \%$, methyl red, kovacs, dan aquadest.

Pengetahuan pedagang dinilai menggunakan kuesioner terstruktur yang terdiri dari 20 pertanyaan. Setiap pertanyaan dengan jawaban benar menghasilkan skor. Skor kemudian dijumlah dan dihitung persentase jawaban benar. Data pengetahuan disajikan dalam bentuk kategori, yaitu baik apabila persentase skor 76-100 \% jawaban benar, cukup apabila persentase skor 56-75\% 
jawaban benar dan kurang apabila persentase skor $\leq 55 \%$ jawaban benar.

Variabel sikap dinilai dengan menggunakan kuesioner terstruktur menggunakan skoring metode Likert dengan skala 5 yang terdiri dari 19 pertanyaan. Setiap pertanyaan positif dengan jawaban sangat setuju diberikan nilai 5, sedangkan pertanyaan negatif yang dijawab sangat setuju diberikan nilai 1. Skor kemudian dijumlah. Data sikap disajikan dalam bentuk kategori, yaitu tinggi jika skor $\geq 69,6$, Sedang apabila skor 44,5-69,5 dan rendah apabila skor $\leq 44,4$.

Variabel tindakan dinilai menggunakan checklist dengan metode Guttman yang terdiri dari 34 indikator. Pedagang diberikan nilai 1 jika list yang diukur dilakukan dan nilai 0 jika tidak dilakukan. Skor kemudian dijumlah. Data tindakan disajikan dalam bentuk kategori, yaitu tinggi jika skor $\geq 22,6$ sedang apabila skor 11,3-22,5 dan rendah apabila skor $\leq 11,2$.

Variabel sanitasi dinilai menggunakan checklist dengan metode Guttman yang terdiri dari 9 indikator. Pedagang diberikan nilai 1 jika list yang diukur dilakukan dan nilai 0 jika tidak dilakukan. Kemudian skor dijumlah. Data sanitasi disajikan dalam bentuk kategori, yaitu tinggi apabila skor $\geq 6$, sedang apabila skor 3-6 dan rendah apabila skor $\leq 3$. Data hasil uji mikrobiologi kemudian dianalisa secara statistik mengunakan uji Spearman's rho dengan derajat kepercayaan 95\% untuk menguji hubungan antara keamanan makanan dengan pengetahuan, sikap, tindakan dan sanitasi.

\section{HASIL DAN PEMBAHASAN}

Sebesar $44 \%$ makanan jajanan yang dijual pedagang di kantin sekolah maupun pedagang keliling terkontaminasi Coliform (> $10 \mathrm{Juml} . / \mathrm{g}$ ). Selengkapnya dapat dilihat pada Tabel 1 .

Tabel 1. Kontaminasi Coliform pada Makanan Jajanan

\begin{tabular}{lcc}
\hline \multicolumn{1}{c}{ MPN Coliform } & $\mathbf{n = 2 5}$ & $\mathbf{\%}$ \\
\hline Memenuhi Syarat & 15 & 60 \\
Tidak Memenuhi Syarat & 10 & 44 \\
\hline
\end{tabular}

Tabel 2. Karakteristik Pedagang

\begin{tabular}{lcc}
\hline \multicolumn{1}{c}{ Karakteristik } & $\mathbf{n = 2 5}$ & $\mathbf{\%}$ \\
\hline Jenis kelamin & & \\
$\quad$ Laki-Laki & 16 & 64 \\
$\quad$ Perempuan & 9 & 36 \\
Kategori Umur & & \\
$\quad>34$ tahun & 19 & 76 \\
28-34 tahun & 4 & 16 \\
$\quad<28$ tahun & 2 & 8 \\
Tempat Berjualan & & \\
$\quad$ Kantin & 10 & 40 \\
$\quad$ Berjualan Keliling & 15 & 60 \\
\hline
\end{tabular}

Tabel 2 menunjukkan mayoritas subyek penelitian ini adalah laki-laki (64\%), pedagang berumur $>34$ tahun (76\%) dan merupakan pedagang keliling yang berjualan di sekitar sekolah $(60 \%)$.

Kontaminasi MPN Coliform pada makanan jajanan sebagian besar $<3,6 \mathrm{Jumlah} / \mathrm{g}$.

Kontaminasi tertinggi coliform yaitu $>1.100$ Jumlah/g, sedangkan kontaminasi terendah $<3,6$ Jumlah/g.

Tabel 3. menunjukkan makanan jajanan yang termasuk kategori memenuhi syarat sebagian besar dijual oleh pedagang yang berjualan keliling di sekitar sekolah (15 makanan jajanan). Sebagian besar pedagang memiliki pengetahuan higiene cukup (52\%), rata-rata skor pengetahuan higiene pedagang 14,64 dari skala 19. Mayoritas pedagang memiliki kategori skor sikap higiene sedang (52\%), dengan rata-rata skor sikap pedagang 69,7 dari skala 83. Skor tindakan mengenai higiene pedagang sebagian besar dalam kategori sedang (56\%), dengan rata-rata skor sebesar 22,16 dari skala 32, sedangkan skor perilaku sanitasi lingkungan pedagang sebagian besar termasuk kategori sedang (56\%) dengan skor rata-rata 5,1 dari skala 9.

Hasil uji statistik Spearman's rho (Tabel 4) menunjukkan terdapat hubungan signifikan antara skor pengetahuan higiene pedagang dengan kadar kontaminasi MPN Coliform ( $p$-value $=0,022)$. Keeratan hubungan antara kedua variabel bernilai $r h o=-0,455^{*}$. Semakin tinggi skor pengetahuan pedagang maka semakin menurun kadar kontaminasi MPN Coliform. Penelitian 
Tabel 3. Kategori Keamanan Makanan Indikator MPN Coliform Berdasarkan Tempat Berjualan

\begin{tabular}{llll}
\hline \multicolumn{1}{c}{ Memenuhi Syarat } & \multicolumn{1}{c}{ Tempat } & \multicolumn{1}{c}{ Tidak Memenuhi Syarat } & \multicolumn{1}{c}{ Tempat } \\
\hline Bakso Bakar (Y-L2) & Berjualan Keliling & Sate Usus (Y-D3) & Kantin \\
Pentol Telur (Y-L1) & Berjualan Keliling & Pentol (Y-L4) & Berjualan Keliling \\
Pempek (Y-L3) & Berjualan Keliling & Pentol (Y-D2) & Kantin \\
Roti Bakar (K3-L2) & Berjualan Keliling & Lontong Balap(Y-D4) & Kantin \\
Pentol(K3-L1) & Berjualan Keliling & Nasi Goreng (Y-D1) & Kantin \\
Pentol(K3-D1) & Kantin & Ote-ote (T4-L3) & Berjualan Keliling \\
Ote-ote (T4-D1) & Kantin & Bakso (S3-D3) & Kantin \\
Papeda (T4-L1) & Berjualan Keliling & Nasi Goreng(S3-D2) & Kantin \\
Telur Gulung(T4-L4) & Berjualan Keliling & Lontong Pecel(S3-D1) & Kantin \\
Sempol Ayam (T4-L2) & Berjualan Keliling & Siomay (S58-L3) & Berjualan Keliling \\
Telur Tusuk (S3-L2) & Berjualan Keliling & & \\
Cireng (S3-L1) & Berjualan Keliling & & \\
Nasi Goreng (S58-K) & Kantin & & \\
Tahu Krispy (S58-L1) Cireng (S58-L1) & Berjualan Keliling & & \\
\hline
\end{tabular}

sejenis lain oleh Sugiyatmi (2006) namun dengan indikator yang berbeda, menunjukkan hasil yang konsisten, yaitu terdapat hubungan signifikan antara pengetahuan dengan keamanan makanan yang dijual di pasar.

Selengkapnya dapat dilihat di Tabel 4. Jika dilihat pada masing-masing item pengetahuan, sebesar $83,6 \%$ pedagang mengetahui tentang kebersihan diri; 70,4\% mengetahui penanganan peralatan masak yang tepat; $74,0 \%$ mengetahui cara penyajian makanan agar tetap bersih; dan

Tabel 4. Kategori Skor Perilaku Pedagang dan Hubungan antara Skor Perilaku Pedagang Kadar Kontaminasi MPN Coliform

\begin{tabular}{|c|c|c|c|c|}
\hline Perilaku & $\mathbf{n}$ & $\%$ & $\mathbf{p}$ & $\mathbf{r}$ \\
\hline \multicolumn{5}{|c|}{ Pengetahuan Higiene } \\
\hline Baik & 9 & 36 & & \\
\hline Cukup & 13 & 52 & $0,022^{*}$ & $-0,455$ \\
\hline Kurang & 3 & 12 & & \\
\hline Mean $\pm S D$ & \multicolumn{4}{|c|}{$14,64 \pm 2,36$} \\
\hline \multicolumn{5}{|l|}{ Skor Sikap } \\
\hline Tinggi & 12 & 48 & & \\
\hline Sedang & 13 & 52 & 0,088 & $-0,349$ \\
\hline Rendah & 0 & 0 & & \\
\hline Mean $\pm S D$ & \multicolumn{4}{|c|}{$69,7 \pm 5,04$} \\
\hline \multicolumn{5}{|l|}{ Skor Tindakan } \\
\hline Tinggi & 11 & 44 & & \\
\hline Sedang & 14 & 56 & $0,005^{* *}$ & $-0,540$ \\
\hline Rendah & 0 & 0 & & \\
\hline Mean $\pm S D$ & \multicolumn{4}{|c|}{$22,16 \pm 4,34$} \\
\hline \multicolumn{5}{|l|}{ Skor Sanitasi } \\
\hline Tinggi & 10 & 40 & & \\
\hline Sedang & 14 & 56 & $0,000^{* *}$ & $-0,651$ \\
\hline Rendah & 1 & 4 & & \\
\hline Mean $\pm S D$ & \multicolumn{4}{|c|}{$5,1 \pm 2,61$} \\
\hline
\end{tabular}

$81,3 \%$ mengetahui fasilitas yang disarankan untuk menjaga kebersihan. Hasil penelitian menunjukkan tidak terdapat hubungan signifikan antara skor sikap higiene pedagang dengan keamanan makanan yang dilihat dari MPN Coliform $(p=0,088)$.

Hasil penelitian ini kontradiksi dengan penelitian Sugiyatmi (2006) yang menunjukkan bahwa sikap pembuat makanan jajanan tradisional di Semarang berhubungan signifikan dengan keamanan makanan jajanan yang dijualnya. Namun penelitian lain oleh Nasution (2009) juga tidak menemukan hubungan signifikan antara sikap mengenai keamanan makanan dengan praktek keamanan makanan. Jika dilihat per item pernyataan mengenai sikap, sebesar $65,3 \%$ pedagang setuju mengenai kebersihan diri ketika berdagang, 76\% setuju agar menggunakan dan merawat peralatan memasak atau makan dengan tepat, $81,3 \%$ pedagang setuju bahwa menyajikan makanan dengan baik dapat menghindari kontaminasi pada makanan jajanan, namun hanya $44 \%$ pedagang yang setuju jika membersihkan sarana berjualan merupakan faktor yang dapat mencegah kontaminasi.

Terdapat hubungan signifikan antara skor tindakan higiene pedagang dengan keamanan makanan yang dilihat dari MPN Coliform ( $p$-value $=0,005)$. Uji keeratan hubungan kedua variabel menunjukkan korelasi sedang $\left(r h o=-0,540^{* *}\right)$. Semakin tinggi skor tindakan higiene pedagang maka semakin menurun kadar kontaminasi MPN Coliform makanan jajanan. Penelitian Susana dan Hartono (2003) 
menunjukkan terdapat hubungan yang signifikan antara kuku tangan penjamah makanan dengan kontaminasi makanan karena kuku merupakan sumber kontaminasi. Faktor lain yang dicurigai dapat memengaruhi keamanan makanan adalah kebiasaan pedagang mengenai mencuci tangan menggunakan sabun sebelum dan sesudah menangani makanan atau melayani pembeli (Susana \& Hartono 2003).

Jika dilihat per item checklist mengenai tindakan higiene pedagang, sebesar $56 \%$ pedagang tidak menjaga kebersihan tangan kuku rambut dan pakaian, 56\% pedagang menggunakan aksesori tangan saat mengolah makanan dan melayani pembeli. Terdapat $40 \%$ pedagang yang memiliki tempat sampah sementara dan $4 \%$ pedagang yang selalu mencuci tangan menggunakan sabun setiap kali akan mengolah atau menangani makanan.

Terdapat hubungan yang bermakna antara skor sanitasi lingkungan pedagang dengan keamanan makanan menggunakan indikator MPN Coliform $(p=0,000)$. Uji keeratan hubungan menunjukkan terdapat korelasi yang tinggi dan negatif antara kedua variabel $\left(\mathrm{r}=-0,651^{* *}\right)$. Semakin tinggi skor sanitasi lingkungan pedagang maka semakin menurun kadar kontaminasi MPN Coliform pada makanan jajanan. Penelitian Riana (2017) menunjukkan faktor yang memengaruhi peningkatan jumlah kontaminasi bakteri Coliform adalah indikator keberadaan pedagang dengan sumber pencemaran. Pedagang yang berjualan di lokasi yang berdekatan dengan sumber pencemaran memicu berpindahnya mikroba berbahaya yang ada di sampah atau sungai ke makanan melalui lalat, serangga, atau udara (Riana, 2017).

Penelitian lain mengenai ketersediaan sarana berdagang menunjukkan bahwa terdapat hubungan yang signifikan antara pedagang yang memiliki tempat sampah sementara dengan keamanan makanan, semakin banyak pedagang yang memiliki tempat sampah sementara semakin rendah pula risiko kontaminasi pada makanan yang dijualnya (Riana, 2017).

Sebesar $20 \%$ pedagang mempunyai tempat sampah tertutup. Tersedianya tempat sampah dapat mengurangi risiko hinggapnya lalat dari tempat sampah yang tidak tertutup ke makanan mentah atau bahkan matang yang sudah matang yang dijual pedagang melalui berbagai media (Riana, 2017).

Pedagang yang memiliki sarana mencuci peralatan (keran) sebesar $44 \%$. Tersedianya keran berarti terdapat fasilitas air mengalir yang dapat digunakan oleh pedagang untuk membersihkan peralatan atau bahan makanan yang akan dimasak. Tersedianya air mengalir dapat mengurangi cemaran mikroba patogen. Pedagang yang menyediakan sabun cuci pada tempat berjualannya hanya sebesar $28 \%$.

\section{KESIMPULAN DAN SARAN}

Ditemukannya $40 \%$ makanan jajanan yang terkontaminasi Coliform perlu diwaspadai. Terdapat hubungan pengetahuan higiene, tindakan higiene dan sanitasi lingkungan pedagang dengan keamanan makanan dengan indikator MPN Coliform, sebaliknya tidak terdapat hubungan antara sikap higiene dengan keamanan makanan dengan indikator MPN Coliform.

Pada penelitian selanjutnya diharapkan observasi mengenai proses pengolahan makanan perlu dilakukan, karena diduga proses pengolahan makanan merupakan salah satu faktor yang dapat memengaruhi kontaminasi Coliform.

\section{PERSANTUNAN}

Peneliti mengucapkan terima kasih kepada ibu dan bapak kepala sekolah di lima SD Negeri maupun swasta yang telah memberikan ijin penelitian, waktu, dan saran yang amat berharga bagi peneliti. Serta ucapan terima kasih bagi seluruh tim laboratorium sanitasi lingkungan di Balai Besar Laboratorium Kesehatan yang telah membantu menganalisis sampel makanan serta memberikan masukan-masukan selama proses analisis hasil mikrobiologi.

\section{DAFTAR PUSTAKA}

BPOM RI. (2011). Laporan Tahunan 2011. Jakarta: Badan Pengawas Obat dan Makanan.

BPOM. (2015). Laporan tahunan badan pengawas obat dan makanan. Jakarta: Badan pengawas diakses di http://www.pom.go.id/ppid/2016/ kelengkapan/laptah2015.pdf. 
BPOM. (2016a). Berita keracunan Januari-Maret 2016. Jakarta: Badan pengawas Diakses dihttp:// ik.pom.go.id/v2016/berita-keracunan/beritakeracunan-bulan-januari-maret-2016.

BPOM. $\left(2016_{\mathrm{b}}\right)$. Berita keracunan April-Juni 2016. Jakarta: Badan pengawas Diakses dihttp:// ik.pom.go.id/v2016/berita-keracunan/beritakeracunan-bulan-januari-maret-2016.

Dinkes Kota Surabaya. (2015). Profil kesehatan tahun 2015. Surabaya: Dinkes Kota Surabaya.

Dinkes Provinsi Jatim. (2012). Profil kesehatan Provinsi Jawa Timur Tahun 2012. Surabaya: Dinas Kesehatan Provinsi Jatim.

Handoyo, A. (2014). Studi kasus kejadian luar biasa keracunan pangan di Desa Jembungan Kecamatan Banyudono Boyolali. Skripsi. Universitas Muhammadiyah Surakarta. Diakses dihttp://eprints.ums.ac.id/32158/13/ NASKAH\%20PUBLIKASI.pdf.

Kristianto, Y. (2013). Faktor determinan pemilihan makanan jajanan pada siswa sekolah dasar. Jurnal Kesehatan Masyarakat Nasional, Vol. 7/No. 11/Juni 2013.

Nasution, A.D.O. (2009). Perilaku penjaja makanan jajanan anak sekolah tentang gizi dan keamanan makanan di lingkungan sekolah dasar kota dan Kabupaten Bogor. Skripsi. Institut Pertanian Bogor.

Riana, Andhita. (2017). Hubungan perilaku higiene dan sanitasi pedagang dengan keamanan makanan jajanan berdasarkan most probably number (MPN) coliform dan escherichia coli
(Unpublished bachelor essay). Universitas Airlangga, Surabaya, Jawa Timur.

Selian, L.S. (2014). Most probable number test and coliform bacteria detection in instant drinks in elementary school at Sukabi District in Bandar Lampung. Journal of Lampung University, [e-journal] 3(2):pp 126-134. Diakses dihttp:// juke.kedokteran.unila.ac.id/index.php/majority/ article/view/203/201.

Sugiyatmi S.H. (2006). Analisis faktor-faktor risiko pencemaran bahan toksik boraks dan pewarna pada makanan jajanan tradisional yang dijual di pasar-pasar Kota Semarang. Tesis. Semarang: Universitas Diponegoro.

Susana, D., \& Hartono, B. (2003). Pemantauan kualitas makanan ketoprak dan gado-gado di lingkungan kampus UI Depok, melalui pemeriksaan bakteriologis. Jurnal Makara, Seri Kesehatan, 7 (1): 56-64. Diakses dihttp:// repository.ui.ac.id/dokumen/lihat/48.pdf.

Thaheer, Hermawan. (2005). Sistem manajemen HACCP (Hazard Analysis Critical Control Points). Jakarta: Bumi Aksara.

Zulaekah, Siti. (2012). Pendidikan gizi dengan media booklet terhadap pengetahuan gizi. Jurnal Kemas Unnes, Volume 7 (2): 102-107. Diakses dihttp://download.portalgaruda.org/ article.php? article $=149816 \&$ val $=5652 \&$ title $=$ PENDIDIKAN\%20GIZI\%20DENGAN\%20 MEDIA \%20BOOKLET\%20TERHADAP\%20 PENGETAHUAN\%20GIZI. 